\title{
8. Sınıf T.C. İnkılap Tarihi ve Atatürkçülük Dersi Konularının Anlatılmasında Sözlü Tarih Metodunun Kullanımına Yönelik Öğretmen Görüssleri ${ }^{1}$
}

\author{
Barlş METINN ${ }^{2} \&$ Mücahid ÖZ $Z^{3}$
}

Özet

Bu çalışma, 8. sınıf T.C. İnkılap Tarihi ve Atatürkçülük dersinde bir yöntem olarak sözlü tarih metodunun kullanımına ilişkin Sosyal Bilgiler öğretmenlerinin görüşlerini belirlemek amacıyla yapılmıştır. Sosyal Bilgiler öğretmenlerin sözlü tarih metodu hakkında görüş ve düşüncelerini dile getirmesi, teoride araştırmalara konu olan sözlü tarih metodu Sosyal Bilgiler öğretmenleri tarafindan pratikte ne kadar kullanılıyor? sorusuna cevap araması ve Sosyal Bilgiler öğretmenlerinin sözlü tarih metodunu kullanırken karşılaştıkları sorunları tespit etme ve sorunların çözümü için öneriler getirme açısından önemlidir.

Araştırmanın örneklem grubunda İstanbul ili Beykoz ilçesi devlet okullarında görev yapmakta olan, 13 Sosyal Bilgiler öğretmeni yer almıştır. Bu araştırmada; "uygun örneklem" tekniği tercih edilmiştir.

Araştırmaya katılan öğretmenlere yarı yapılandırılmış mülakat uygulanmıştır. Çalışma sonunda mülakat sorularına verilen cevaplar, daha önce konu üzerinde edinilen bilgiler ışığında betimsel olarak yorumlanmıştır.

Araştırma sonucunda elde edilen bulgulara göre; Sosyal Bilgiler öğretmenlerinin sözlü tarih metodu hakkında temel bilgilere sahip oldukları, bu metodun kullanılması gerektiği, bu metodun kullanılmasının öğrenciye ve tarih öğretimine katkılarının olduğu ancak bu metodun kullanımının bazı sınırlılıkları olduğu sonucuna ulaşılmıştır. Araştırmanın sonucunda elde edilen bulgular doğrultusunda problemin çözümüne ilişkin önerilere yer verilmiştir.

Anahtar Kelimeler: Sözlü Tarih Metodu, 8. Sınıf Türkiye Cumhuriyeti İnkılap Tarihi ve Atatürkçülük Dersi, Eğitim.

\section{Teacher Views Toward The Use Of Oral Historical Method In Teaching 8th Grade Revolution History Of Turkish Republic And Kemalism Lesson}

\begin{abstract}
This study aims to determine social sciences teachers' opinion regarding use of oral history method as a technique in 8th grade Turkish Republic Revolution History and Kemalism lesson. To express Social sciences teachers their opinion and thoughts about oral history method is important with regard to try to find an answer the question of how often oral history method which is the subject of research in theory is used by social sciences teachers in practice and to identify problems faced by social sciences teachers in using oral history method and to provide suggestions them for solving problems.
\end{abstract}

13 social sciences teachers who work in İstanbul Beykoz district public schools took part in sample group of the research. In this study "convenience sampling" technique was preferred.

Semi-structured interview was implemented to teachers who participate the research. At the end of the study the answers to interview questions were interpreted in a descriptive way in the light of previously obtained information.

According to the findings obtained from the research it is concluded that oral history method should be used, the use of oral history method has positive contribution on students, oral history method has contribution on history teaching and the use of oral history method has some limitations. In the direction of findings of the research suggestion are given regarding the solutions of the problem.

Key Words: Oral History Method, 8th Grade Turkish Republic Revolution History and Kemalism Lesson, Education

\footnotetext{
${ }^{1}$ Bu makale yüksek lisans tezinden türetilmiştir

2 Doç. Dr., Uşak Üniversitesi, Eğitim Fakültesi, Sosyal Bilimler Anabilim Dalı, baris.metin@usak.edu.tr

3 mücahidozz@gmail.com
} 


\section{Giriş}

Eğitim, bireyde kendi yaşantısı ve kasıtlı kültürleme yoluyla istenilen davranış değişikliğini meydana getirme sürecidir. $\mathrm{Bu}$ süreç sonunda bireylerin bilgilerinde, davranışlarında ya da özelliklerinde bir değişim olmalıdır. Bu değişimin önceden belirlenmiş amaçlara göre olması, eğitimi; maksatlı olarak istenilen davranışları kazandırma süreci olarak karşımıza çıkarmaktadır. Okullarda yapılan her türlü eğitim kasıtlı kültürlemeye örnektir. Okullarda yapılan eğitim de toplumun ihtiyaçları doğrultusunda şekillenmektedir (Demirel 1999: 7).

Toplumların ve bireylerin ihtiyaçlarının karşılanması eğitim programları vasıtasıyla olmaktadır (Arslan ve Demirel 2007: 198). Eğitim programı, öğrenene okulda ve okul dışında planlanmış etkinlikler yoluyla sağlanan yaşantılar düzeneği olarak tanımlanabilir (Demirel 2004: 4). Zamanla, değişen istek ve amaçlara göre değişikliklere uğrayan ve zamanla ihtiyaçlara, amaçlara karşılık veremeyen programların yerine değişim ve gelişmelere uygun yeni programlar hazırlanır. Eğitimin davranış değiştirme süreci olarak tanımlanması, eğitim programlarının dinamik ve sürekli bir yaşantılar bütünü olarak görülmesine ve program geliştirme çalışmalarında ağırlığın, öğretme öğrenme süreçleri üzerinde yoğunlaşmasına yol açmıştır (Fidan 1996: 2).

“Türk Eğitim sistemi 2004 yılında başlayan sistematik bir program geliş̧tirme sürecine girmiş ve ilköğretim öğretim programlarından üniversite ögretim programlarına kadar tüm programlarda köklü değişiklikler gerçekleştirilmiştir', (Bulut 2008: 521). Yeni bir eğitim felsefesi anlayışıyla, eğitim ve öğretim programları yeniden hazırlanmış ve köklü değişime ilk adım atılmıştır. Nitekim eğitimin çeşitli kademelerini kapsayacak şekilde yapılandırılan bu eğitim programları, yapılandırmacı yaklaşım ve dünyadaki yeni ve çağdaş eğilimler doğrultusunda düzenlenmiştir (Erdoğan 2007: 225). Yapılan bu değişim neticesinde çağın eğitim anlayışına cevap verebilen, toplumu ve bireyi göz önüne alan bir metoda doğru gidilmiştir. Geleneksel öğretim yöntemleri bireyi merkeze almayan, pasif alıcı olarak görmekteydi ve sorgulamadan, anlamlandırmaya ihtiyaç duymadan sadece ezberlemesini yeterli bulan bir öğretim anlayışı bulunmaktaydı. Yeni eğitim anlayışıyla öğenciye düşen görev, yeni ile eski bilgiler arasında bağlantı kurmak ve anlamı yapılandırmaktır. Yapılandırmacılıkta öğrenme bir sonuç değil, süreç olarak karşımıza çıkmaktadır. Bilgi, öğrenci zihnine olduğu gibi depolanmaz. İnsan zihni bilgilerin depolandığı boş bir depo değildir (Akpınar 2010: 18). Bireyin yeni bilgiler keşfetmesi ve bildiklerini anlamlandırması şeklinde tanımlanabilen yapılandırmacı öğrenme yaklaşımında; bilginin sorgulanması, yorumlanması ve analiz edilmesi bir süreç olarak esas alınır (Karadağ vd. 2008: 396).

Derslerin kazanımları, uygulanan etkinlikler ve ders işleniş biçimleri dikkate alındığında yeni programlarla birlikte tarih dersleri birer bilgi yığını olmaktan çıkmıştır. Özellikle tarih konuları önceki programlarda ezberlenmekten öteye gidemezken, yeni sosyal bilgiler ve tarih derslerindeki etkinlik ve yöntemler aracılığıyla, tarih biliminin yapısına uygun adımlar atılarak tarihi anlama bilinci 
aşılanmaktadır (İncegül 2010: 13 ). Tarih bilincine sahip bireyler yetiştirmek, tarih dersi öğretim programının temel amaçları arasındadır. Eğitim-öğretim alanındaki gelişmelerin uygulanan yöntem ve teknikler ile öğretim programlarına yansıması kaçınılmazdır. Bu ihtiyaçlar doğrultusunda öğretim programlarında yeni yaklaşımlar dikkat çekmektedir.

$\mathrm{Bu}$ yaklaşımlardan biri tarihsel sorgulamaya dayalı araştırma becerisi olan sözlü tarih çalışmalarıdır. Bu yaklaşım olaylara tanıklık eden insanların konuşturulduğu, farklı bakış açıları ve farklı geçmişlere sahip insanların çıkar, inanış ve fikirlerini yansıttığı iyi bir sorgulama türüdür. Sözlü tarih çalışmaları öğrencilerin ders kitabındaki bilgileri sorgulamasını, olaylar hakkında yeni sorular sormasını, ders kitabında yer verilmeyen tarihi şahsiyetlerin bakış açılarını araştırmasını ve ders kitabının tamamıyla veya kısmen göz ardı ettiği bir konuyu derinlemesine inceleyebilmesini sağlar.

'Sözlü tarih yönteminin işlenişi ve faydaları incelendiğinde öğrencilerin tarih derslerinde aktif hale geldiği, bilgiyi ezberlemediği, aksine sorguladı̆̆l, kendisini ve yaşadĭ̆ toplumu fark ettiği, zaman ve mekânı fak edip ayırt etmeyi öğrendiği, bir sosyal bilimci gibi problem çözme basamaklarını takip ederek sorgulayıcı düşünme biçimi ile "küçük birer sosyal bilimci”, tarihi konuları ele alışı, inceleyişi kanıtlar toplayarak yorumlarda bulunma çabaları ile "küçük birer tarihçi" olma duygusunu yaşayabildikleri görülmektedir"' (İncegül 2010: 13).

Etkinliklerin öğrenci yetenek ve ilgilerine göre planlanması öğrenciyi aktif kılma ve bilginin yapılandırılması hususunda oldukça önemlidir. Sözlü tarih yöntemi de öğrenciyi aktifleştirme ve bilgiyi kendi yetenek ve ilgilerine göre yapılandırmalarında önemli rol oynamaktadır (Demircioğlu 2005: 52). Dolayısıyla öğrenciye söz konusu becerilerin kazandırılması, öğretmenlerin derslerde uygun etkinlikleri yapmasıyla mümkün olmaktadır. Bununla birlikte öğretmenler de eğitim öğretim etkinliklerini planlarken ve uygularken birtakım yeterliliklere de sahip olmalıdır (Metin ve Oran 2014: 208).

\section{Sözlü Tarih}

Geçmiş hakkında bilgiye ulaşmada tarihçilerin en büyük yardımcıları yazılı kaynaklardır. Fakat bunun yanı sıra tarihçilerin kullandığı başka tür kaynaklar da mevcuttur. Bunlardan biri de sözlü kaynak metodudur. Sözlü kaynakların sağladığı en önemli avantajlardan biri yazılı kaynaklardan ulaşılamayan bazı bilgilere ulaşmamızı sağlamasıdır. Çünkü resmi yazışmalar, mahkeme tutanakları ve ticaret anlaşmaları gibi arşivlenen bazı yazılı kaynaklar öncelikle devlet ve toplum arasındaki ilişkiye yönelik bilgiler verir. Bunun yanı sıra yazılı kaynaklar okuma yazma bilen kesimi temsil ederken toplumun alt kesiminde yaşayanların durumunu yansıtmaz (Avcı Akçalı ve Aslan 2012: 678).

Hâlihazırdaki tarih anlayışlarına alternatif bir yöntem olmak yerine tarihin daha iyi anlamlandırılması için yeni fırsatlar sunan sözlü tarih, tarih araştırmalarında görülen yeni yöntemlerden biridir. Sıradan insanların hayat hikâyesinin de tarihin bir parçası olduğu kanısından yola çıkan sözlü tarih, disiplinler arası iş birliği yönü ile sosyoloji, antropoloji, etnoloji, folklor, psikoloji, sosyal psikoloji, coğrafya gibi beşeri bilimlerin tüm imkânlarından yararlanmaktadır (Metin 2002: 288). 
Sözlü tarih konusunda uzman olan Paul Thompson, sözlü tarihi, insanların söylediklerini dinlemekten ve belleklerini kullanmaktan kaynaklanan bir tarih biçimidir, şeklinde tanımlamaktadır (Thompson 1999: 152).

Stephen Caunce, sözlü tarihi bir kaynak ve malzeme toplama yöntemi olarak görmektedir. Ona göre sözlü tarih günümüzü daha iyi anlamak ve geleceği daha iyi yönlendirebilmek için geçmişe bir anlam katma sürecine yapılan katkıdır (Caunce 2001: 225).

Baum'a göre ise sözlü tarih bir tarihsel bilgi toplama yöntemidir. $O$, sözlü tarihi kendi içinde bir konu olarak değil bir yöntem ve veri toplama metodolojisi olarak görür. Sözlü tarih belirli bir olayın yaşandığı dönemde yaşamış, bir olaya doğrudan ya da dolaylı iştirak etmiş ya da bir olaya şahitlik eden insanların tecrübelerini doğrudan dinleme şansı bulmuş kişilerden veri elde etme yöntemidir. Sözlü tarih kaydedilmiş rastgele bir görüşme değil belirli bir konun planlı, yapılandırılmış ya da yarı-yapılandırılmış dolaysız bir şekilde işlenmesidir (Baum 1987: 1).

Creswell ise sözlü tarihi; araştırmacının bir bireyden ya da bireylerden olayların kişisel hatırlamasını, sebeplerini ve etkilerini topladığı bir yaklaşım olarak tanımlamaktadır (Creswell 1998: 49).

\section{Eğitimde Kullanılabilecek Bir Yöntem Olarak Sözlü Tarih}

Sözlü tarih, tarihin veri toplama aracı olmasının yanı sıra eğitim faaliyetleri ile bütünleşmiş bir öğrenme ve öğretme yöntemidir. Bu yöntemin kullanıldığı sınıflarda öğretmenler sözlü tarihi bir öğretim yöntemi, öğrencilerde bir öğrenme yöntemi olarak kullanır. Aslında tam olarak öğretim ve öğrenme süreçlerinin bir sentezidir diyebiliriz (Dere 2017: 33).

II. Dünya savaşı sonrasında Avrupa'da sözlü tarihin akademik tarihçilikte yerini almasından sonra bu yöntem eğitim alanında da kendini göstermiş ve tarih eğitiminde pek fazla kullanılır olmuştur. Özellikle yakın tarihin anlaşılması çocukların güdülenme düzeylerini yükseltir. Okullarda çocuklar ailelerinin tarihleri üzerine projeler gerçekleştirmeleri, böylece çevrelerini daha geniş bir geçmişle ilişkilendirebilmeleri sözlü tarih yöntemiyle mümkün olabilir (Sarı 2007: 47).

İlk, orta ve yükseköğretim düzeyinde kullanılabilecek olan sözlü tarih yöntemine dayalı öğretim etkinlikleri süreci dört basamağa ayrılmaktadır;

1. Hazırlık aşaması: Birinci / İkinci el kaynakların incelenmesi, görüşme yapılacak kişinin / kişilerin belirlenmesi, görüşme sorularının belirlenmesi.

2. Uygulama aşaması: Belirlenen soruların sorulması ve yanıtların kaydedilmesi

(teyp, kamera, not alma gibi), kaydedilen verilerin çözümlenmesi.

3. Rapor edilme aşaması: Verilerin düzenlenmesi, birinci / ikinci el kaynaklarla karşılaştırılması / desteklenmesi, raporun yazılması. 
4. Sınıfta sunum aşaması: Hazırlanan çalışmanın öğrencilere sınıfta sunulması ve gerekli düzeltmelerin yapıldığı aşamadır. Ayrıca öğretmenlere, velilere ve tüm tarih meraklılarına bir sergi aracılığılla sunum yapılabilir (Kabapınar 2007: 20).

Safran ve Ata (1998; 5) sözlü tarih etkinliğinin kullanma hazırlıklarını şöyle sıralamaktadır:

*Konunun seçilmesi

*Görüşme yapılacak kişilerin belirlenmesi

*Soruların hazırlanması

*Görüşmenin düzenlenmesi

*Görüşmeden elde edilen bilgilerin düzenlenmesi

*Etkinliğin toparlanmas1

Sözlü tarih sürecinin yoğunluğu nedeniyle öğretmenlerin konuları 2-3 kişiden oluşan gruplara vermeleri, niteliğin artması ve sosyalleşmenin hızlanması noktasında da önemlidir. Bu çerçevede de sözlü tarihin önemli bir başka yönü de ortaya çıkmaktadır. Nitekim bu sayede sözlü tarih yöntemi rekabete dayanan bir çalışma olmaktan öte, grup dayanışmasını geliştirir ve pekiştirir. Ayrıca gruplar bir arada araştırma yapmanın ve başarmanın tadına varma olanağına sahip olacaklardır (İncegül 2010: 13).

“'Sözlü tarih yöntemiyle ögrrenci, geçmişte yaşamış insanların günlük yaşantılarıly ilgili bilgi sahibi olur, bunu, kendi yaşam koşullarıyla karşılaştırarak değişim ve sürekliliği algılar'” (Safran ve Ata 1998; 5). "Sözlü tarihin eğitim alanında kullanılması, öğrenciyi tarih dersi kitabının içerisinden çıkartıp, tarihe bambaşka bir yerlerden yaklaşmasını sağlar. Bunun yanında kimsenin bilmediği ya da kimsenin aklına gelmeyen bir konu saptayıp, yepyeni bir dünya keşfetmesini mümkün kılar', (Sar1 2007; 110). “Ayrıca öğrencilerin kendilerini daha sonra tarih sahnesinde ortaya çıkacak birer tarih oyuncusu olarak görmeye başlamalarına imkân sağlayabilir', (Sarı 2006; 122).

Okullarda sözlü tarih yönteminin kullanılmasının öğrencilere kazandırdığı beceriler şöyle sıralanabilir.

*Dinleme

*Gözlem

*Soru sorma

*Bilgiyi düzenleme

*Olguyu düşünceden ayırma

*İlgisiz bilgi arasından ilgili bilgiyi bulma 
*Kendilerinden önceki kuşakları daha iyi anlama ve takdir etme

*Değişim ve sürekliliği algılama (Safran ve Ata 1998; 6).

Öğrenciye bahsedilen becerilerin kazandırılması derslerde uygun etkinliklerin yapılmasıyla mümkün olmaktadır. Etkinliklerin öğrencilerin ilgi ve yeteneklerine göre planlanması öğrenciyi aktif kılma ve bilginin yapılandırılması konusunda oldukça önemlidir. Sözlü tarih yöntemi de öğrenciyi aktif hale getirme ve bilgiyi kendi yetenek ve ilgilerine göre yapılandırmalarında önemli bir rol oynamaktadır (Demircioğlu 2005: 52).

\section{Sözlü Tarih Yöntemini Kullanırken Dikkat Edilecek Hususlar}

Bir öğretim yöntemi olarak sözlü tarih etkinliklerini uygun ve doğru bir şekilde yapılabilmesi için iyi bir planlamaya ihtiyaç duyulmaktadır. Bu bağlamda, öğretmenlerin sözlü tarih metoduna dair etkinlikleri planlarken dikkat etmeleri gereken hususlar şöyle sıralanabilir:

*Dersin hedef ve davranışlarının 1şığı altında işlenilecek konuya uygun bir sözlü tarih çalışma alanı belirlenir.

*Sözlü tarih çalışmasıyla öğrencilere kazandırılacak olan nitelik ve beceriler açıkça ortaya konulur.

*Sözlü tarih öğretim etkinliklerinin sınıf dışında yapılması halinde, çalışmanın yapılacağı kişiler belirlenir.

*Öğrencilere sözlü tarih esnasında kullanacakları mülakat etkinliği hakkında bilgi verilir. Bu çerçevede, mülakat sorulan nasıl hazırlanır, nasıl sorulur, mülakat esnasında nelere dikkat edilir, elde edilen veriler nasıl yorumlanır ve sözlü tarih etkinliği sonucu bir raporun nasıl hazırlanacağı öğrencilere öğretilir.

*Çalışmanın nasıl yürütüleceğine yönelik bilgilendirilmelerinin ardından öğrenci grupları belirlenir.

*Sınıf dışında yapılacak çalışmalarda aileler ve milli eğitimden gerekli izinler alınır.

*Sözlü tarihe dayalı çalışma sonucunda davranış değişikliklerinin meydana gelip gelmediğini görmek amacıyla, ne tür ölçme ve değerlendirme yaklaşımlarının uygulanacağına karar verilir.

*Sözlü tarih çalışmasından elde edilen sonuç ve deneyimlerin sınıfta nasıl paylaşılabileceği planlanır (Demircioğlu 2005: 52). 


\section{Yöntem}

Araştırmada nitel araştırma tekniklerinden olgubilim (fenomenoloji) deseni uygulanmıştır. Olgubilim araştırmalarında veri kaynakları araştırmanın odaklandığı olguyu yaşayan ve bu olguyu dışa vurabilecek veya yansıtabilecek bireyler ya da gruplardır. Olgubilim araştırmalarında veri analizi, yaşantıları ve anlamları ortaya çıkarmaya yöneliktir. Bu amaçla yapılan içerik analizinde verinin kavramsallaştırılması ve olguyu tanımlayabilecek temaların ortaya çıkarılması çabası vardır. Sonuçlar betimsel bir anlatım ile sunulur ve sık sık doğrudan alıntılara yer verilir. Bunun yanında ortaya çıkan temalar ve örüntüler çerçevesinde elde edilen bulgular açıklanır ve yorumlanır (Yıldırım ve Şimşek 2008: 39).

Nitel araştırma tekniklerinden olgubilim deseni bu araştırmada, 8. sınıf T.C. İnkılap Tarihi ve Atatürkçülük derslerinde sözlü tarihin yeri ve kullanımına ilişkin öğretmen görüşlerini genel hatlarıyla tespit etmek ve anlamak amacıyla kullanılmıştır. Araştırmaya katılan öğretmenlere açık uçlu sorular sorularak nitel veri toplama tekniklerinden yarı yapılandırılmış mülakat uygulanmıştır. Görüşme formu hazırlandıktan sonra Sosyal Bilgiler Eğitimi ana bilim dalında görev yapan 3 akademisyenden uzman görüşü alınmış ve geri bildirimler çerçevesinde soru sayısı 5'e indirilmiştir. Son aşamada esas uygulamaya dâhil olmayan 2 Sosyal Bilgiler öğretmenine görüşme formunun anlaşıla bilirliğini test etmek için pilot uygulama yapılmıştır. Bunun sonucunda görüşme formu son halini almıştır. Çalışma sonunda mülakat sorularına verilen cevaplar, daha önce konu üzerinde edinilen bilgiler ışığında betimsel olarak yorumlanmıştır.

\section{Çalışma Grubu}

Araştırmanın örneklem grubunda İstanbul ili Beykoz ilçesi devlet okullarında görev yapmakta olan, 13 Sosyal Bilgiler öğretmeni yer almıştır. Katılımcıların 8'i erkek, 5'i ise kadındır. Bu araştırmada katılımcıların belirlenmesinde amaçlı örnekleme tekniklerinden biri olan "uygun örnekleme tekniği", tercih edilmiştir. Araştırma etiği gereği öğretmenlerin kimlik bilgileri gizli tutulmuş ve öğretmenlere “Ö1, Ö2”’ gibi kodlar verilmiştir.

\section{Verilerin Analizi}

Araştırmaya katılan Sosyal Bilgiler öğretmenlerinin sözlü tarih metodu hakkındaki görüşleri ve sözlü tarih metodunun kullanımına yönelik mülakat sorularına verdikleri cevaplar incelenmiştir. Mülakat esnasında araştırmaya katılan öğretmenlerin mülakat sorularına verdikleri cevaplar ses kaydına alınarak Word dosyasına aktarılmıştır. Daha sonra görüşme yapılan öğretmenlerin verdikleri cevaplara kodlamalar yapılmıştır ve veriler analiz edilmiştir. Yapılan mülakatların analizi sırasında veriler, kodlama yoluyla Sosyal Bilgiler Eğitimi ana bilim dalında görev yapmakta olan 3 uzman tarafından kategorilere ayrılmıştır. Veriler sonucunda ilk etapta; birinci sorudan 18, ikinci sorudan 10, üçüncü sorudan 22, dördüncü sorudan 27 , beşinci sorudan 11 kod olmak üzere toplamda 88 koda ayrılmıştır. 
Daha sonra bu kodlar kendi aralarında ilişkilendirilerek kod sayısı 33'e düşürülmüştür. Çalışma sonunda mülakat sorularına verilen cevaplar, daha önce konu üzerinde edinilen bilgiler ışığında betimsel olarak yorumlanmıştır.

Tablo 1.

Soru Başlıklarına iliş̧kin Kodlar.

\begin{tabular}{|c|c|}
\hline $\begin{array}{l}\text { "Sözlü tarih metodu hakkında düşünce ve } \\
\text { görüşleriniz nelerdir?” soru başlığına ilişkin } \\
\text { kodlar }\end{array}$ & $\begin{array}{l}\text { Yakın çevre, Kalıcı öğrenme, Anı, Merak, Birinci } \\
\text { elden kaynaklar, Deneyim, Aktif katılım, Araştırma } \\
\text { becerisi }\end{array}$ \\
\hline $\begin{array}{l}\text { “8. sınıf T.C. İnkılap Tarihi ve Atatürkçülük } \\
\text { dersinde sözlü tarih metodunu kullanıyor } \\
\text { musunuz? Gerekçeleriyle açıklar mısınız?” soru } \\
\text { başlığına ilişkin kodlar }\end{array}$ & $\begin{array}{l}\text { Doküman eksikliği, Kaynakların ulaşılabilirliği, } \\
\text { Yakın tarih, Müfredat yoğunluğu, Süre yetersizliği }\end{array}$ \\
\hline $\begin{array}{l}\text { “Sözlü tarih metodunun } 8 \text {. sınıf T.C. İnkılap } \\
\text { Tarihi ve Atatürkçülük dersinde kullanılmasına } \\
\text { yönelik görüşleriniz nelerdir? Gerekçeleriyle } \\
\text { açıklar mısınız?” soru başlığına ilişkin kodlar }\end{array}$ & $\begin{array}{l}\text { Somutlaştırma, Milli bilinç, Aktif katılım, Öğrenci } \\
\text { merkezci, Aidiyet hissi, İlgi, İşbirlikçi sınıf, Çift yönlü } \\
\text { iletişim }\end{array}$ \\
\hline $\begin{array}{l}\text { “Sözlü tarih metodunun } 8 \text {. sınıf T.C. İnkılap } \\
\text { Tarihi ve Atatürkçülük dersinde kullanılmasının } \\
\text { öğrenciye sağlayacağı yararlar hakkında ne } \\
\text { düşünüyorsunuz?” soru başlığına ilişkin kodlar }\end{array}$ & $\begin{array}{l}\text { Eğlenerek öğrenme, Farklı bakış açısı, Geçmiş ile } \\
\text { bağ kurma, Anlamlı bilgi, Karşılıklı öğrenme, Dikkat } \\
\text { çekme, Tarihsel düşünme becerisi, Problem çözme } \\
\text { becerisi }\end{array}$ \\
\hline $\begin{array}{l}\text { “Sözlü Tarih Metodunu 8. sınıf T.C. İnkılap } \\
\text { Tarihi ve Atatürkçülük Dersinde Kullanırken } \\
\text { Herhangi Bir Sorun İle Karşılaşıyor Musunuz?” } \\
\text { soru başlığına ilişkin kodlar }\end{array}$ & $\begin{array}{l}\text { Bilginin güvenilirliği, Kaynak yetersizliği, Sınav } \\
\text { odaklı müfredat, Ders saati yetersizliği }\end{array}$ \\
\hline
\end{tabular}

\section{Bulgular}

Sosyal Bilgiler öğretmenlerine görüşmede 1. soru olarak " Sözlü tarih metodu hakkında düşünce ve görüşleriniz nelerdir? " sorusu yöneltilmiştir. Görüşmeye katılan Sosyal Bilgiler öğretmenlerinin 12 tanesi sözlü tarih metodu hakkında olumlu görüş bildirirken 1 tanesi olumsuz görüş bildirmiştir. Araştırmaya katılan 5 öğretmen birinci elden kaynak kullanımına ve öğrenmenin yakın çevreden yapıldığına değinerek sözlü tarih metodunun; bilginin kalıcılığı ve anlamlandırılması konusunda faydalı olacağını ve dersin daha keyifli geçeceğine vurgu yapmıştır.

'Sözlü tarih, çocukların birinci elden kaynaklardan, kendi deneyimleri ile bilgi toplayıp daha sonra bu bilgileri düzenleyip sınıfta sunmalarını sağlayan bir metot. Öğrencilerin derse aktif katılımını sağladığından hem ögrencilerin hem bizim daha keyifli bir ders geçirmemizi sağlayabilir." (Ö1) 
“Birinci el kaynak olması ve dönemin şartlarını anlayabilmemiz açısından önemli bir metot. Ayrıca öğrenci kendi araştırmasını yaptı̆̆ı için bilginin anlamlandırılması ve kalıcı olması açısından da faydalı olacaktır." (Ö7)

Bulgulardan anlaşılacağı üzere Sosyal Bilgiler öğretmenleri sözlü tarih metodu ile ilgili temel bilgilere sahiplerdir. 13 öğretmenden 12 tanesi sözlü tarih metodu hakkında olumlu görüş bildirmiştir. Olumsuz görüş bildiren öğretmen ise 8. sınıf T.C. İnkılap Tarihi ve Atatürkçülük derslerinde sözlü tarih metodunun kullanımının uygunsuz olduğunu bildirmiştir.

Sosyal Bilgiler öğretmenlerine görüşmede 2. soru olarak " 8 . sınıf T.C. İnkılap Tarihi ve Atatürkçülük dersinde sözlü tarih metodunu kullanıyor musunuz? Gerekçeleriyle açıklar mısınız?", sorusu yöneltilmiştir. Görüşmeye katılan 13 Sosyal Bilgiler öğretmeninden 9 tanesi 8. sınıf T.C. İnkılap Tarihi ve Atatürkçülük dersinde sözlü tarih metodunu kullandığını söylerken, 4 öğretmen kullanmadığını söylemiştir. Derslerinde sözlü tarih metodunu kullandığını belirten öğretmenlerden 5 öğretmen de çok sık kullanamadıklarını dile getirmişlerdir. Sözlü tarih metoduna 8. sınıf T.C. İnkılap Tarihi ve Atatürkçülük derslerinde yer veren öğretmenlerin öncelikli nedenleri arasında; öğrencilerin kendi deneyimleri ile öğrenme gerçekleştirmeleri, yakın çevreden öğrenilen bilgilerin kalıcı olduğu, öğrencileri sürece aktif katması, ezberci anlayıştan uzak anlamlı öğrenmelere firsat vermesi, derse ve konuya karşı ilgiyi arttırması, dersi eğlenceli hale getirmesi gibi nedenler bulunmaktadır.

“Evet kullanıyorum. Mesela, Kore Savaşı, Kıbris Barış Harekâtı ve yakın tarihimizdeki konuları anlatırken yararlandım. Öğrenci derse aktif olarak katıldı̆̆g için, bilgilerin kalıcıllğı konusunda faydalı oluyor ve bu da bilgiyi ezberlemekten öte anlamlı ögrenmelere firsat tanıyor.' (Ö8)

"Evet kullanıyorum. Benim bizzat duyduğum ya da duyanlardan dinlediğim olaylart yeri geldiği zaman anlatıyorum. Bunun yanında konuya göre yakın çevrelerinden bilgiler toplamalarını da istiyorum. Daha sonra topladıkları bilgileri sınıfta sunmalarını ve arkadaşlarıyla paylaşmalarını istiyorum. Tüm bunlar sonucunda çocuk kendi araştırdĭ̆ı, deneyimlediği konuyu daha iyi öğreniyor. Hele bir de yakın çevresinden öğrendiği zaman çok daha faydalı bir ders oluyor. ' (Ö5)

Bu bulgulardan hareketle araştırmaya katılan Sosyal Bilgiler öğretmenlerinin büyük çoğunluğu 8. sınıf T.C. İnkılap Tarihi ve Atatürkçülük derslerinde sözlü tarih metodunu çok sık olmasa da kullanmaya çalıştı̆̆ görülmüştür. Derslerinde sözlü tarih metoduna yeteri kadar yer veremeyen ya da kullanamayan öğretmenlerinde, bu durumun sebepleri olarak müfredatın uygunsuzluğu, ders saatlerinin yetersizliği ve sınav odaklı ders işleme zorunluluğu olduğu söylenebilir.

Sosyal Bilgiler öğretmenlerine görüşmede 3. soru olarak "Sözlü tarih metodunun 8. sınıf T.C. İnkılap Tarihi ve Atatürkçülük dersinde kullanılmasına yönelik görüşleriniz nelerdir? Gerekçeleriyle açıklar mısınız?" sorusu yöneltilmiştir. Araştırmaya katılan Sosyal Bilgiler öğretmenlerin tamamı sözlü tarih metodunun 8. sınıf T.C. İnkılap Tarihi ve Atatürkçülük dersinde kullanılması gerektiğini belirtmişlerdir. Görüşme yapılan Sosyal Bilgiler öğretmenleri; öğrencilerin sözlü tarih metodu sayesinde 
birinci elden kaynakları kullanarak derse karşı ilgilerinin arttığını, sürece aktif olarak katıldıkları için bilginin anlamlandırmasında ve kalıcı olmasına katkı sağladığını, eleştirel düşünce ve farklı bir bakış açısı kazandırdığını ve derslerin eğlenceli geçmesine katk1 sağladığı yönünde görüş belirtmişlerdir. Sosyal Bilgiler öğretmenleri bunlardan dolayı 8. sınıf T.C. İnkılap Tarihi ve Atatürkçülük derslerinde sözlü tarih metodunu kullanımını olumlu bulduklarını belirtmişlerdir.

"Sosyal Bilgiler müfredatında daha çok öneri olarak karşımıza çıkıyor fakat İnkılap Tarihi müfredatında da yer almalı ve kesinlikle kullanılmall. Dersleri slkıcı olmaktan ve kolay unutulur olmaktan çıkarıyor. Öğrencilerin aktif katılımını sağladı̆̆ için de öğrenci merkezli bir ders işlememize olanak veriyor.", (Ö8)

“Sözlü tarih metodu tarih ögretiminde oldukça faydalı olduğunu düşünüyorum. Çocukların derse karşı ilgilerini çekmesi, farklı bir bakış açısı geliştirmeleri açısından, çocukların çevrelerine ve tarih konularına ilgi duymaları açısından oldukça faydalı buluyorum. ', (Ö9)

"Kesinlikle kullanılmalı ve bununla ilgili yapılan çalışmalar artırılmalı. Kendi deneyimleri sonucunda ögrenilen bilgiler daha kalıcı ve anlamlı olacaktır. Ve bu sayede tarih dersleri de daha ĕglenceli olacaktır." (Ö6)

Görüldüğü gibi araştırmaya katılan Sosyal Bilgiler öğretmenlerinin tamamı sözlü tarihin 8. sınıf T.C. İnkılap Tarihi ve Atatürkçülük derslerinde kullanılması hususunda olumlu görüş belirtmişlerdir. Araştırmaya katılan öğretmenlerin çoğu ise sözlü tarihin 8. sınıf T.C. İnkılap Tarihi ve Atatürkçülük derslerinde kullanılmasının öğrencide derse karşı ilgi oluşacağını, kendi deneyimleri sonucu gerçekleşen öğrenmelerin daha anlamlı ve kalıcı olacağını ve derslerin eğlenceli geçeceğini belirtmişlerdir. Araştırmaya katılan bazı Sosyal Bilgiler öğretmenleri ise sözlü tarih metodunun 8. sınıf T.C. İnkılap Tarihi ve Atatürkçülük derslerinde kullanılması gerektiğini belirtirken ders müfredatında ve ders saatlerinde düzenlemeler yapılması gerektiğini savunarak kaynak hususunda ve bilginin objektifliği konusunda dikkat edilmesi gerektiğini belirtmişlerdir.

Sosyal Bilgiler öğretmenlerine görüşmede 4. soru olarak "Sözlü tarih metodunun 8. sinıf T.C. İnkılap Tarihi ve Atatürkçülük dersinde kullanılmasının öğrenciye sağlayacağı yararlar hakkında ne düşünüyorsunuz?’' sorusu yöneltilmiştir. Bu sorunun yanıtına ilişkin Sosyal Bilgiler öğretmenleri derslerde sözlü tarih metoduna yer verildiği takdirde öğrencilerin derse karşı olumlu tutumlar geliştirebileceği ve öğrenciye bazı yararlar sağlayacağı yönünde görüş belirttikleri görülmektedir. Araştırmaya katılan Sosyal Bilgiler öğretmenleri öğrencide öğrenilen bilgilerin kalıcılığı, tarih derslerine olan ilgiyi arttırma, dersin daha eğlenceli geçmesi, geçmiş ile günümüz arasında bağ kurmasına olanak vermesi, farklı bir bakış açısı kazandırma, araştırma becerisi kazandırma ve milli bir bilinç oluşumuna katkı sağlaması bakımından yararlar sağlayacağını ifade etmişlerdir. 
“Bilgiyi kendileri bulup çıkaracaklar, biz vermeden kendi yakın çevrelerinden öğrendikleri için daha kalıcı ve anlamlı bilgiler öğrenecekler. Bu da öğrenci merkezli eğitim anlayışına daha uygun oluyor." (Ö3)

'Sözlü tarih metodu; geçmişi daha iyi anlamaya katku sağlayarak öğrenilen bilgilerin kalıcılı olmasına faydalı olur. Ve ögrenirken eğlenmeyi de beraberinde getirir.,' (Ö10)

"Çocuklar bu metot sayesinde tarihi neden ögrendiğini anlamlandırır ve farkına varır. Tarih ile günümüz arasında bir băg kurabilirler.", (Ö4)

“"̈̈̆renciler yakın çevrelerinden olayları yaşamış insanlardan doğrudan bilgi aldıkları için bilgiyi üretme sürecine dâhil oluyorlar. Bunun sonucunda tarih dersleri daha eğlenceli ve faydalı hale gelebilir diye düşünüyorum.' (Ö13).

Bulgulardan hareketle sözlü tarih metodu sayesinde 8. sınıf T.C. İnkılap Tarihi ve Atatürkçülük derslerinde öğrenilen bilgilerin kalıcı olmasına, öğrencilerin derse karşı olumlu bir tutum kazanmalarına katkı sağlayarak dersleri sıkıcı olmaktan kurtarabilir. Eleştirel düşünce ve araştırma becerisi kazanmalarına, geçmiş ile günümüz arasında bir kurmaya, öğrencilerde tarihimize karşı aidiyet hissi gelişmesine ve milli bir bilinç oluşmasına katkı sağlayabileceği söylenebilir.

Sosyal Bilgiler öğretmenlerine görüşmede 5. soru olarak "Sözlü Tarih Metodunu 8. sınıf T.C. İnkılap Tarihi ve Atatürkçülük Dersinde Kullanırken Herhangi Bir Sorun İle Karşılaşıyor Musunuz?’ sorusu yöneltilmiştir. Bu sorunun yanıtına ilişkin araştırmaya katılan Sosyal Bilgiler öğretmenlerin çoğunluğu sözlü tarih metodunu kullanırken birtakım sorunlarla karşılaştıklarını ifade etmişlerdir. Sosyal Bilgiler öğretmenleri; ders saatlerinin yetersizliği, müfredatın uygunsuzluğu ve yoğunluğu, kaynak kişiye ulaşma, izinler, maddi sorunlar ve bilginin güvenirliği bakımından sorunlar yaşadıklarını ifade etmişlerdir. 3 Sosyal Bilgiler Öğretmeni ise herhangi bir sorun ile karşılaşmadığını dile getirmiştir. 2 Sosyal Bilgiler öğretmeni ise yine benzer sebeplerden dolayı sözlü tarih metodunu uygulayamadığını ifade etmiştir.

Ders sürelerinin yetersizliği konusuna değinerek sözlü tarih metodunu kullanırken sorunlar yaşayan Sosyal Bilgiler öğretmenlerinin ifadeleri şu şekildedir;

“İnklap Tarihi derslerinde sözlü tarih metodunu kullanırken oldukça zorlanlyorum çünkü konular zaten yetişmiyor. Yeri geldiği zaman başka derslerde hocalardan izin isteyip ekstra ders yapmak zorunda kalyyoruz. Hal böyleyken sözlü tarih metoduna zaman ayırı uygulamak oldukça zor bir hal alıyor.", (Ö9)

“Özellikle 8. sinıflarda teog sinavı olduğundan bu metot ile ders işlemek oldukça zor oluyor. Aynı zamanda İnkılap Tarihi ders saatlerinin azlığı sözlü tarih çalışması yapmak için oldukça kısıtlayıcı oluyor.' (Ö10) 
“Bu tarz etkinlikleri uygulamak için İnkılap Tarihi ders saatleri çok az. Bırakın sözlü tarih metodu gibi çocukların sürece aktif olarak katıldı̆̆ zaman gerektiren metotları kullanmayl, sınava yönelik konuları hızlı bir şekilde anlatırken bile yetişmiyor." (Ö5)

Araştırmaya katılan Sosyal Bilgiler öğretmenlerinin büyük çoğunluğu sözlü tarih metodunu derslerinde kullanırken bir sorun ile karşılaştı̆̆ını, bazıları da benzer sebeplerden dolayı sözlü tarih metodunu derslerde hiç kullanamadığını ifade etmiştir. Bu sorunlar arasında en fazla müfredat, bilginin güvenilirliği ve ders saatlerinin yetersizliği ile ilgili sorunlar yaşadıklarını belirtmiştir. Bu sorunları kaynak kişiye ulaşma, izinler ve maddi sıkıntılar takip etmiştir. Bunun yanında az sayıda Sosyal Bilgiler öğretmeni de 8. sınıf T.C ve İnkılap Tarihi ve Atatürkçülük derslerinde sözlü tarih metodunu kullanırken herhangi bir sorun ile karşılaşmadığını savunmuştur.

Tüm bu bulgulardan yararlanarak 8. sınıf T.C İnkılap Tarihi ve Atatürkçülük dersinde sözlü tarih çalışmalarına yer vermek için çok fazla zamana ihtiyaç duyulacağı, daha çok yakın tarihimizi ilgilendiren konularda sözlü tarih metodundan daha verimli bir şekilde faydalanılacağı söylenebilir. Ayrıca kaynaklardan edinilecek bilgilerin yanlış, eksik ya da sübjektif olma ihtimali olduğundan sözlü tarih metodunu uygularken öğretmenlerin dikkatli olmaları ve gerekli kontrollerin yapılması gerektiği söylenebilir.

\section{Tartışma}

Sosyal Bilgiler öğretmenlerinin 8. sınıf T.C. İnkılap Tarihi ve Atatürkçülük dersinde sözlü tarih metodu kullanımına ilişkin görüşlerini belirlemek hedeflenmiştir. Bu hedefler doğrultusunda Sosyal Bilgiler öğretmenleri ile yapılan görüşme sonucunda verdikleri cevaplar analiz edilmiştir. Sözlü tarih metodu ile ilgili yapılan diğer araştırmaların literatür taraması sonucunda; yapılan akademik eserlerin çoğu sözlü tarih metodunun ne olduğu ve nasıl uygulandığı ile ilgili teorik bilgiler içerir (Sarı 2006; Kaya 2013).

Çalışmamızı destekler nitelikte olan Kandemir'in (2017) yaptığı çalışmada; Ortaöğretim Tarih öğretmenlerinin tarih öğretiminde sözlü tarihin ve sözlü tarih kaynaklarının yeri ve kullanımına ilişkin öğretmen görüşlerini araştırmıştır. Araştırmada elde edilen bulgulara göre, tarih öğretmenlerinin sözlü tarih hakkında mevcut bilgiye sahip oldukları, tarih öğretiminde sözlü tarih çalışmalarına yer verilmesinin faydalı olacağı, tüm öğretmenlerin derslerinde sözlü tarih çalışmaları yaptıkları ve bu çalışmalara uygulamada kullanılmasının tarih öğretimi açısından olumlu sonuçlar doğurabileceğini savunmuştur. Tarih öğretmenlerinin; sözlü tarih ile ilgili görüşleri, sözlü tarih çalışmalarının öğrencilere katkı sağladığını beyan etmeleri, sözlü tarihin sınırlılıkları ve bu sınırlılıklara yönelik sunduğu öneriler açısından iki çalışma birbirini destekler niteliktedir. 
“Sosyal Bilgiler öğretmenlerinin sözlü tarih metodu hakkında görüş ve düşüncüleri nelerdir?" alt problemine ilişsin tartışma.

Araştırmaya katılan Sosyal Bilgiler öğretmenlerinin çoğu sözlü tarih metodu hakkında olumlu görüş bildirmişlerdir. Araştırmaya katılan Sosyal Bilgiler öğretmenleri, birinci elden kaynak kullanımına ve öğrenmenin yakın çevreden yapıldığına değinerek sözlü tarih metodunun; bilginin kalıcılığı ve anlamlandırılması konusunda faydalı olacağını ve dersin daha keyifli geçeceğine vurgu yapmışlardır. Bazı öğretmenler ise sözlü tarih metodunun milli bilinç ve aidiyet hissinin oluşmasına katkı sağlayacağını savunmuşlardır.

Kandemir (2017), çalışmasında Ortaöğretim Tarih öğretmenlerinin sözlü tarih hakkındaki görüşlerini araştırmış ve araştırmaya katılan öğretmenler sözlü tarih kaynakları hakkında olumlu görüş bildirmişlerdir. $\mathrm{Bu}$ çalışmada sözlü tarih metodu değil, sözlü tarih ve sözlü tarihin kaynakları araştırıldığından söz konu alt probleme ilişkin bir karşılaştırma yapılması uygun değildir. Sözlü tarih metodunun araştırıldığı diğer akademik çalışmalarda öğretmen görüşlerine yer veren bir çalışmaya rastlanmamıştır.

'Sosyal Bilgiler öğretmenlerinin 8. sınıf T.C. İnkılap Tarihi ve Atatürkçülük dersi konularının anlatılmasında sözlü tarih metodunun kullanılmasının öğrenciye sağlayacağı yararlar hakkındaki görüşleri nelerdir?'” alt problemine ilişkin tartışma.

Araştırmaya katılan Sosyal Bilgiler öğretmenleri, derslerde sözlü tarih metoduna yer verildiği takdirde öğrencilerin derse karşı olumlu tutumlar geliştirebileceği ve öğrenciye yararlar sağlayacağı yönünde görüş belirttikleri görülmektedir. Araştırmaya katılan Sosyal Bilgiler öğretmenleri öğrencide öğrenilen bilgilerin kalıcılığı, tarih derslerine olan ilgiyi arttırma, derslerim daha eğlenceli geçmesi, geçmiş ile günümüz arasında bağ kurmasına olanak vermesi, farklı bir bakış açısı kazandırma, araştırma becerisi kazandırma ve milli bir bilinç oluşumuna katkı sağlaması bakımından yararlar sağlayacağını ifade etmişlerdir.

Sözlü tarih metodunun kullanımının öğrenciye faydaları açısından araştırmamız ile paralellik gösteren aşağıdaki çalışmalarda; Sarı(2002), çalışmasında sözlü tarih yöntemine dayalı tarih öğretimi ile tarih derslerinin daha ilginç ve zihinde daha kalıcı olabileceğini savunmuştur. Sarı'ya (2007) ait başka bir çalışmada; 7. sınıf "Yurdumuzun Komşuları" ünitesi "Kuzey Kıbrıs Türk Cumhuriyeti" konusu sözlü tarih yöntemi ile işlenmiştir. Konunun işlenişinde Kıbrıs gazisinden yararlanılmıştır. Yapılan bu çalışma sonucu, öğrencilerin başarısının arttı̆̆ı, bilgiyi düzenleme, olguyu düşünceden ayırma, ilgisiz bilgi arasından ilgiliyi bulma, tarihsel empati kurma ve değişim ve sürekliliği algılama becerilerini geliştirdiğini ileri sürülmektedir. Sarı'ya ait iki çalışma da sözlü tarih metodunun kullanılmasının öğrenciye faydaları açısından karşılaştırıldığında, çalışmamız ile birbirlerini destekler niteliktedir. 
Yine sözlü tarih metodunun öğrenciye sağlayacağı yararları bakımından çalışmamız ile birbirini destekleyen Kandemir'e (2017) ait çalışma incelendiğinde; sözlü tarih etkinlikleri ile işlenen derslerin öğrencilerin derse olan ilgisini arttıracağını, öğrencilere problem çözme ve eleştirel beceri kazandıracağını, kalıcı öğrenmeler kazanmalarına katkıda bulunacağını savunmuştur. Öğrencilerin derse karş1 olumlu tutum sergilemesine ve öğrenciyi araştırmaya sevk edebileceğini de savunmuştur. Sözlü tarih çalışmalarının öğrenciye birçok açıdan fayda sağlayacağını savunan söz konusu çalışma ile araştırmamız birbiri ile paralellik göstermektedir.

Öğrencilerin derse karşı tutumlarının değişmesi ve eğlenceli bir ders işlediklerini savunması ve öğrenci başarısının artığını savunması açısından İncegül'ün (2010) çalışması ile araştırmamız birbiri ile paralel ve birbirini destekler niteliktedir. İncegül, yapmış olduğu "Sosyal Bilgiler Dersinde Örnek Bir Sözlü Tarih Uygulaması" adlı yüksek lisans teziyle 5.sınıf Sosyal Bilgiler dersinin öğretiminde "Kültür ve Miras" öğrenme alanı içinde yer alan "Geçmişimi Öğreniyorum" adlı ünite bağlamında oyun ve oyuncağın tarihi sözlü tarih yöntemi kullanılarak araştırılmıştır. Yapılan çalışma sonrası öğrencilerin tarih ve Sosyal Bilgiler dersine karşı bakış açılarının değiştiği ve eğlenceli bir ders geçirdiklerini, öğrenci başarısının arttığını savunmuştur.

“Sosyal Bilgiler öğretmenlerinin 8. sınıf T.C. İnkılap Tarihi ve Atatürkçülük dersinde sözlü tarih metodunu kullanıp kullanmama durumları ve sebeplerine yönelik görüşleri nelerdir?’’ alt problemine ilişkin tartışma.

Görüşmeye katılan 13 Sosyal Bilgiler öğretmeninden 9 tanesi 8. sınıf T.C. İnkılap Tarihi ve Atatürkçülük dersinde sözlü tarih metodunu kullandığını söylerken, 4 öğretmen kullanmadığını söylemiştir. Sözlü tarih metoduna 8. sınıf T.C. İnkılap Tarihi ve Atatürkçülük derslerinde yer veren öğretmenlerin öncelikli nedenleri arasında; öğrencilerin kendi deneyimleri ile öğrenme gerçekleştirmeleri, yakın çevreden öğrenilen bilgilerin kalıcı olduğu, öğrencileri sürece aktif katması, ezberci anlayıştan uzak anlamlı öğrenmelere firsat vermesi, derse ve konuya karşı ilgiyi arttırması, dersi eğlenceli hale getirmesi gibi nedenler bulunmaktadır.

Tarih öğretmenlerinin sözlü tarih metodunu kullanma gerekçelerini araştıran Kandemir'in (2017) çalışması ile çalışmamız; araştırmaya katılan ve derslerinde sözlü tarih metodunu kullanan öğretmenlerin, derslerinde sözlü tarih metodunu kullanma gerekçeleri açısından birbiri ile paralellik göstermektedir. Kandemir (2017), çalışmasında Ortaöğretim Tarih öğretmenlerine; derslerinde sözlü tarih çalışmalarına yer verip vermediklerini, yer verip vermeme gerekçelerini sormuş ve araştırmaya katılan öğretmenlerin tamamının derslerinde sözlü tarih çalışmasına yer verdiğini belirmiştir. Tarih öğretmenlerinin derslerinde sözlü tarih çalışmalarına yer vermelerinin gerekçeleri olarak da; öğrenciyi aktif kılması, dersi zevkli hale getirmesi, öğrencilerin bilgiye kendisinin ulaşması, kalıcı öğrenmeler sağlaması, öğrencileri ezbercilikten kurtarması, öğrencilerin tarihsel düşünce becerilerini geliştirmesi gibi nedenler olduğunu belirtmiştir. 
Söz konusu iki çalışma; öğretmenlerin sözlü tarih metodunu derslerde kullanma sayıları açısından farklı1ık göstermiştir. Kandemir'in çalışmasında araştırmaya katılan 10 öğretmenin tamamı sözlü tarih çalışmalarına yer verirken bu çalışmada araştırmaya katılan 13 öğretmenin 9 tanesi sözlü tarih metodunu kullanırken 4 tanesi sözlü tarih metodunu derslerinde kullanamadığını belirtmiştir.

Söz konusu iki çalışmada, araştırmaya katılan ve derslerinde sözlü tarih metodunu kullanan öğretmenlerin, derslerinde sözlü tarih metodunu kullanma gerekçeleri açısından birbiri ile paralellik göstermektedir.

‘'Sosyal Bilgiler öğretmenlerinin 8. sınıf T.C. İnkılap Tarihi ve Atatürkçülük dersinde sözlü tarih metodunu kullanırken karşılaştıkları sorunlara yönelik görüşleri nelerdir?’” alt problemine ilişkin tartışma.

Araştırmaya katılan Sosyal Bilgiler öğretmenlerin çoğunluğu sözlü tarih metodunu kullanırken birtakım sorunlarla karşılaşıklarını ifade etmişlerdir. Sosyal Bilgiler öğretmenleri; ders saatlerinin yetersizliği, müfredatın uygunsuzluğu ve yoğunluğu, kaynak kişiye ulaşma, izinler, maddi sorunlar ve bilginin güvenirliği gibi sorunlar yaşadıklarını ifade etmişlerdir.

Kandemir'in (2017) çalışması ile araştırmamızı karşılaştırdığımızda; söz konusu iki çalışma arasında benzerlikler ve farklılıklar olduğu ortaya çıkmaktadır. Kandemir çalışmasında Ortaöğretim Tarih öğretmenleri derslerinde sözlü tarih çalışmalarına yer vermelerinin bazı sınırlılıkları olduğunu savunmuştur. Bu çalışmada dile getirilen sınırlılıklar; müfredatın yoğun olması, ders saatlerinin yetersiz olması, sınıfların kalabalık olması, eksik yanlış ya da sübjektif bilgi barındırma olasılığının olması şeklinde sıralanmıştır.

Söz konuş çalışmalar, sözlü tarih metodunun kullanımının yanında getirdiği sınırlılıklar ve sorunlara ilişkin değerlendirildiğinde birbirini destekler ve tamamlar nitelikte olduğu söylenebilir. İki çalışmada da ders saatlerinin yetersizliği, müfredatın yoğunluğu, bilginin güvenilirliği ve sübjektifliği konusunda paralellik göstermektedir. Araştırmamızda Kandemir'in çalışmasından farklı olarak kaynak kişiye ulaşma, izin alma süreçleri ve maddi sorunlar gibi sorunları da dile getirilmiştir.

\section{Sonuçlar}

Bu çalışmada sözlü tarih metodu, sözlü tarih metodunun amaçları, sözlü tarih metodunun faydaları, sınırlılıkları ve sınıfta sözlü tarih metodu kullanılırken nelere dikkat edilmesi gerektiği belirtilmiştir. Ayrıca bu çalışma ile Sosyal Bilgiler öğretmenlerinin sözlü tarih metodu ile ilgili düşünce ve görüşleri, 8. sınıf T.C. İnkılap Tarihi ve Atatürkçülük dersinde sözlü tarih metodunu kullanıp kullanmadıkları, sözlü tarih metodunun , 8. sınıf T.C. İnkılap Tarihi ve Atatürkçülük dersinde kullanılmasına yönelik görüşleri, sözlü tarih metodunun kullanılmasıyla öğrenciye sağlayacağı yararlar hakkındaki görüşleri ve sözlü tarih metodunu , 8. sınıf T.C. İnkılap Tarihi ve Atatürkçülük dersinde kullanırken herhangi bir sorun ile karşılaşılması hakkındaki düşünce ve görüşleri ortaya konmuştur. 
“'Sözlü tarih metodu hakkında düşünce ve görüşleriniz nelerdir?’’ sorusuna araştırmaya katılan Sosyal Bilgiler öğretmenlerin çoğu sözlü tarih metodunun önemine ve faydalarına değinerek olumlu görüş belitmişlerdir. Ayrıca araştırmaya katılan bazı öğretmenler mevcut müfredat ile sözlü tarih metodunun uyumsuzluğunu dile getirmiştir. Bu görüşler doğrultusunda araştırmaya katılan Sosyal bilgiler öğretmenlerinin sözlü tarih metodu hakkında temel bilgilere sahip olduğu söylenebilir.

“8. sınıf T.C. İnkılap Tarihi ve Atatürkçülük dersinde sözlü tarih metodunu kullanıyor musunuz?' sorusuna araştırmaya katılan Sosyal Bilgiler öğretmenlerinin çoğu derslerinde sözlü tarih metodunu kullandıklarını belirtmişlerdir. Bu görüşe sahip öğretmenlerin bir kısmı yeteri kadar yer veremediklerini de dile getirmişlerdir. Araştırmaya katılan Sosyal Bilgiler öğretmenleri sözlü tarih metodunu derslerinde kullanmaları nedenleri arasında; öğrencilerin kendi deneyimleri ile öğrenme gerçekleştirmeleri, yakın çevreden öğrenilen bilgilerin kalıcı olduğu, öğrencileri sürece aktif katması, ezberci anlayıştan uzak anlamlı öğrenmelere fırsat vermesi, derse ve konuya karşı ilgiyi arttırması, dersi eğlenceli hale getirmesi gibi nedenler bulunmaktadır. Ayrıca az da olsa bazı öğretmenler derslerinde sözlü tarih metodunu kullanamadıklarını dile getirmiştir. Derslerinde sözlü tarih metoduna yeteri kadar yer veremeyen ya da kullanamayan öğretmenlerin, bu durumun sebepleri olarak müfredatın uygunsuzluğu, ders saatlerinin yetersizliği ve sınav odaklı ders işleme zorunluluğu olduğu tespit edilmiştir.

“Sözlü tarih metodunun 8. sınıf T.C. İnkılap Tarihi ve Atatürkçülük dersinde kullanılmasına yönelik görüşleriniz nelerdir? Gerekçeleriyle açıklar mısınız?' sorusuna araştırmaya katılan öğretmenlerin tamamı olumlu görüş belirterek sözlü tarih metodunun 8. sınıf T.C. İnkılap Tarihi ve Atatürkçülük derslerinde kullanılması gerektiğini belirtmiştir. Araştırmaya katılan öğretmenlerin çoğu ise sözlü tarihin 8. sınıf T.C. İnkılap Tarihi ve Atatürkçülük derslerinde kullanılmasının öğrencide derse karşı ilgi oluşacağını, kendi deneyimleri sonucu gerçekleşen öğrenmelerin daha anlamlı ve kalıcı olacağını ve derslerin eğlenceli geçeceğini belirtmiş̧lerdir. Araştırmaya katılan bazı Sosyal Bilgiler öğretmenleri ise sözlü tarih metodunun 8. sınıf T.C. İnkılap Tarihi derslerinde kullanılması gerektiğini belirtirken ders müfredatında ve ders saatlerinde düzenlemeler yapılması gerektiğini savunarak kaynak hususunda ve bilginin objektifliği konusunda dikkat edilmesi gerektiğini belirtmişlerdir.

“'Sözlü tarih metodunun 8. sınıf T.C. İnkılap Tarihi ve Atatürkçülük dersinde kullanılmasının öğrenciye sağlayacağı yararlar hakkında ne düşünüyorsunuz?’' sorusuna araştırmaya katılan Sosyal Bilgiler öğretmenleri çeşitli faydalara değinmişlerdir. Sözlü tarih metodu sayesinde 8. sinıf T.C. İnkılap Tarihi ve Atatürkçülük derslerinde öğrenilen bilgilerin kalıcı olmasına, öğrencilerin derse karşı olumlu bir tutum kazanmalarına katkı sağlayarak dersleri sıkıcı olmaktan kurtarabilir. Eleştirel düşünce ve araştırma becerisi kazanmalarına, geçmiş ile günümüz arasında bir kurmaya, öğrencilerde tarihimize karşı aidiyet hissi gelişmesine ve milli bir bilinç oluşmasına katkı sağlayabileceği tespit edilmiştir. 
“Sözlü tarih metodunu 8. sınıf T.C. İnkılap Tarihi ve Atatürkçülük dersinde kullanırken herhangi bir sorun ile karşılaşıyor musunuz?" sorusuna araştırmaya katılan Sosyal Bilgiler Öğretmenlerinin büyük çoğunluğu sözlü tarih metodunu derslerinde kullanırken sorunlar ile karşılaştıklarını, bazıları da benzer sebeplerden dolayı sözlü tarih metodunu derslerde hiç kullanamadıklarını ifade etmiştir. Bu sorunlar arsında en fazla müfredat, bilginin güvenilirliği ve ders saatlerinin yetersizliği ile ilgili sorunlar yaşadıklarını belirtmiştir. Bu sorunları kaynak kişiye ulaşma, izinler ve maddi sıkıntılar takip etmiştir. Bunun yanında az sayıda Sosyal Bilgiler Öğretmeni de 8. sınıf T.C. ve İnkılap Tarihi ve Atatürkçülük derslerinde sözlü tarih metodunu kullanırken herhangi bir sorun ile karşılaşmadığını savunmuştur.

\section{Öneriler}

\section{Milli Eğitim Bakanlığı İçin Öneriler}

1. 8. sınıf T.C. İnkılap Tarihi ve Atatürkçülük dersi ders saatleri arttırılmalıdır. 8. sınıf T.C İnkılap Tarihi ve Atatürkçülük müfredat programı yoğun olduğu ve öğrencinin sürece aktif olarak katıldığı, zaman gerektiren etkinliklerin uygulanmasının oldukça zor olduğu görüşü belirtilmiştir.

2. Sözlü tarih çalışmaları yapılarak tarih öğretiminde kullanılmak üzere öğretmenlerin ve öğrencilerin yararlanabileceği, kolay bir şekilde ulaşabilecekleri, tarihsel dönemlere göre ayrılmış bir sözlü tarih kaynağı oluşturulabilir. Bu kaynaktan yararlanılacak bilgilerin güvenilirliği ve doğruluğu kontrol edilerek hem sözlü tarih metodunun sınırlılıkları azaltılmış olur hem de isteyen herkesin yararlanabileceği güvenilir kaynaklar sayesinde sözlü tarih metoduna başlamadan önce öğretmenlere ve öğrencilere bir örnek oluşturabilir.

3. Öğrencilerin derse aktif olarak katılacağı etkinliklere daha çok yer vermek adına müfredat yoğunluğu azaltılabilir. Araştırmaya katılan öğretmenler müfredatın yoğunluğundan dolayı sözlü tarih metoduna yer veremediklerini belirtmiştir.

4. Müfredata yakın tarihimize ait konular daha çok eklenebilir. Bu sayede sözlü tarih metodunu öğretmenler daha verimli kullanabilirler ve sözlü tarih metodundan daha çok fayda sağlanabilir. Araştırmaya katılan bazı ögretmenler müfredatta yakın tarihimize ait konular olmamasından dolayı sözlü tarih metodunu kullanamadıklarını ifade etmişlerdir.

5. Öğretmenlere sözlü tarih metodu hakkında hizmet içi eğitimler vererek, öğretmenlerin sözlü tarih metodu hakkında bilgi sahibi olmaları sağlanabilir. Bu eğitimler sayesinde derslerde aktif olarak kullanılması özendirilebilir. 


\section{Program Geliştirme Uzmanları İçin Öneriler}

1. Sözlü tarih metodunu verimli bir şekilde kullanmak adına öğretmen kılavuz kitaplarda uygulanışını hakkında zenginleştirilmiş örnekler ile bilgi verilebilir. Öğretmenlerin sözlü tarih metodu hakkında bilgi sahibi olduğu fakat uygulama konusunda farklı görüşlere sahip oldukları tespit edilmiştir.

2. Ders kitaplarında öğrencinin sürece aktif olarak katıldığı sözlü tarih metodu ve benzeri yöntemler öneri olarak verildiği görülmüştür. Ders kitaplarına sözlü tarih metodu vb. yöntemler öneri olmaktan öteye giderek uygulanması zorunlu tutulabilir ve özendirilebilir.

\section{Öğretmenler İçin Öneriler}

1. Derslerinde sözlü tarih çalışmalarına ve öğrenciyi aktif kılarak öğrenmeleri daha anlamlı hale getiren vb. yöntemlere daha sık yer verebilirler.

2. Sözlü tarih metodunu kullanırken veliler ile işbirliği yaparak, velilere yöntem hakkında bilgi verebilirler. Böylece sözlü tarih metodunun etkisi artabilir.

3. Sözlü tarih metodu, öğretmen kılavuz kitaplarında öneri olarak yer verilmiş ve sözlü tarih metodu değerlendirme ölçeği de eklenmiştir. Sözlü tarih metodunu daha sık kullanmaları önerilmektedir ve sözlü tarih metodunu uyguladıktan sonra sözlü tarih değerlendirme ölçeğini de kullanmaları önerilmektedir.

4. Sözlü tarih metodunu kullanırken öğrencilere rehberlik etmeleri önerilmektedir.

\section{Alanda Araştırma Yapacak Araştırmacılar İçin Öneriler}

1. 8. sınıf T.C. İnkılap Tarihi ve Atatürkçülük dersi kapsamında uygulamalı olarak örnek bir sözlü tarih çalışması yapabilirler.

2. Bu çalışma İstanbul ilinin Beykoz ilçesinde yapılmıştır. Farklı bir il ya da ilçe de benzer bir çalışma yapılarak sözlü tarih metodu hakkında öğretmen görüşleri alınabilir.

3. Sözlü tarih metodu hakkındaki öğretmen görüşlerini; yaş, cinsiyet ve mezun olunan bölüm gibi ölçütlerle karşılaştırılarak araştırma yapılabilir.

4. Üniversite öğrencilerinin, sözlü tarih metodu hakkında bilgi düzeylerini ve görüşlerini ölçen bir araştırma yapılabilir. 


\section{Kaynakça}

Akpınar, Burhan (2010) "Yapılandırmacı Yaklaşımda Öğretmenin, Öğrencinin ve Velinin Rolü’. Eğitim Bir Sen Dergisi, 6 (16). 15-20

Arslan, Ali ve Demirel, Özcan (2007) “'Ilköğretim 5. Sınıf yeni Sosyal Bilgiler Programının Değerlendirilmesi”. Milli Ĕgitim Dergisi. 175: 198-208.

Avcı Akçalı, Aslı ve Aslan, Erdal (2012) “Tarih Öğretiminin İyileştirilmesi Yolunda Alternatif Bir Yöntem: Sözlü Tarih”. Kastamonu Eğitim Dergisi, 20 (2), 669-688.

Baum, Willa K. (1987) Oral History for the Local Historical Society. Nashwille: American for State and Local History.

Bulut, İlhami (2008) "Yeni İlköğretim Programlarında Öngörülen Öğrenci Merkezli Uygulamalara İlişkin Öğretmen Görüşleri (Diyarbakır ili örneği)". Kuram ve Uygulamada Eğitim Yönetimi, 56, 521-546.

Caunce, Stephen (2001) Sözlü Tarih ve Yerel Tarihçi. (Çev: B. Bülent Can ve Alper Yalçınkaya). İstanbul: Tarih Vakfi Yurt Yayınları.

Creswell, John W. (1998) Qualilitative Inguiry and Research Desing: Choosing Among Five Traditions. Thousend Oaks, CA: Sage.

Demircioğlu, İsmail Hakkı (2005) Tarih Öğretiminde Öğrenci Merkezli Yaklaşımlar. Anı Yayıncılık, 52.

Demirel, Özcan (1999) Öğretme sanatı. Ankara: Pegem Akademi Yayınları.

Demirel, Özcan (2004) Kuramdan Uygulamaya Eğitimde Program Geliştirme. Ankara: Pegem Akademi Yayıncilik.

Dere, İlker (2017) Sosyal Bilgiler Derslerinde Bir Öğretme ve Öğrenme Yöntemi Olarak Sözlü Tarih. Doktora Tezi, Uşak Üniversitesi Sosyal Bilimler Enstitüsü, Uşak.

Erdoğan, Mehmet (2007) "Yeni Geliştirilen Dördüncü ve Beşinci Sınıf Fen ve Teknoloji Dersi Öğretim Programının Analizi; Nitel Bir Çalışma". Türk Eğitim Bilimleri Dergisi, 5(2), 221-254.

Fidan, Nurettin (1996) Okulda öğrenme ve ögrretme. Eğitim Psikolojisi. Ankara: Alkım Yayınevi.

İncegül, Sibel (2010). Sosyal Bilgiler Dersinde Örnek Bir Sözlü Tarih Uygulaması. Yüksek lisans tezi, Marmara Üniversitesi, Eğitim Bilimleri Enstitüsü.

Kabapınar, Yücel (2007) İlköğretimde Hayat Bilgisi ve Sosyal Bilgiler Öğretimi. Ankara: Maya Akademi.

Kandemir, Kübra (2017) Tarih Öğretiminde Sözlü Tarihin Yeri ve Kullanımına İlişsin Öğretmen Görüşleri. Yüksek Lisans Tezi, Atatürk Üniversitesi, Eğitim Bilimleri Enstitüsü.

Karadağ, Engin, Deniz, Sevgi ve Korkmaz, Tuğba (2008). "Yapılandırmacı Öğrenme Yaklaşımı: Sınıf Öğretmenleri Görüşleri Kapsamında Bir Araştırma”. Uludağ Üniversitesi Eğitim Fakültesi Dergisi, 21(2), 383402.

Kaya, Meryem (2013) Sosyal Bilgiler Dersinde Kullanılabilecek Bir Öğretim Yöntemi Olarak Sözlü Tarih: Amaç, İçerik, Uygulama. Yayımlanmamış yüksek lisans tezi, Marmara Üniversitesi, Eğitim Bilimleri Enstitüsü.

Metin, Barış ve Oran, Mehmet (2014) "İlköğretim Sosyal Bilgiler Öğretmenlerinin Ders İçi Yerel Tarih Konusundaki Faaliyetleri Uşak İli Örneği”. Uşsak Üniversitesi Sosyal Bilimler Dergisi. 7(1), 204-216.

Metin, Celal (2002) “Sözlü Tarih ve Türkiye'deki Gelişimi”. Türk Kültürü Dergisi, 40(469), 288-299.

Safran, Mustafa ve Ata, Bahri (2006). “'Okul Dışı Tarih Öğretimi”’. Tarih Eğitimi Makale ve Bildiriler. Ankara: Gazi Kitabevi.

Sarı, İbrahim (2002) Sosyal Bilgiler Dersi Tarih Ünitelerinde Bir Yöntem Olarak Sözlü Tarih. Ankara: Gazi Üniversitesi Eğitim Bilimleri Enstitüsü.

Sarı, İbrahim (2006) “Akademik Tarih ve Tarih Öğretiminde Sözlü Tarihin Yeri ve Önemi’”. Türkiye Sosyal Araştırmalar Dergisi. 10(3), 109-122.

Sarı, İbrahim (2007) Sosyal Bilgiler Öğretiminde Sözlü Tarih Etkinliklerinin Öğrenci Başarı, Beceri ve Tutumlarına Etkisi. Doktora Tezi, Gazi Üniversitesi Eğitim Bilimler Enstitüsü, Ankara.

Thompson, Paul (1999) Geçmisin Sesi: Sözlü Tarih. (Çev: S.Layıkel). İstanbul: Tarih Vakfı Yurt Yayınları. 
Yıldırım, Ali ve Simsek, Hasan (2008). “Sosyal Bilimlerde Nitel Araştırma Yöntemleri”. Ankara: Seçkin Yayınevi. 